\title{
The Effects of Parabiosis on Serum and Kidney Glycosidase Activities in Spontaneously Diabetic Mice
}

\author{
H. Fushimi ${ }^{1}$, K. Nonaka ${ }^{2}$, S. Tarui ${ }^{2}$, Y. Tochino ${ }^{3}$, and H. Kanaya ${ }^{3}$ \\ ${ }^{1}$ Department of Medicine, Sumitomo Hospital, Nakanoshima, ${ }^{2}$ Second Department of Medicine, \\ Osaka University School of Medicine, Fukushima, and ${ }^{3}$ Shionogi Laboratory, Sagisu, Osaka, Japan
}

Summary. Spontaneously diabetic non-obese mice of the ICR strain were newly inbred in Shionogi laboratory, Japan. Animals became diabetic suddenly, more frequently and severely in females. Blood glucose levels were $452 \pm 73 \mathrm{mg} / 100 \mathrm{ml}$ with serum insulin levels of $<1.0 \mu \mathrm{U} / \mathrm{ml}$ in the fed state. Parabiosis with normal control ICR mice for 2 weeks decreased the blood glucose level to $260 \pm 51 \mathrm{mg} /$ $100 \mathrm{ml}(\mathrm{P}<0.01)$ and resulted in serum insulin levels of $46.0 \pm 18.0 \mu \mathrm{U} / \mathrm{ml}(\mathrm{P}<0.01)$. Kidney homogenate $\beta$-N-acetylglucosaminidase and $\beta$-galactosidase activities were reduced in diabetic mice (42\% and $44 \%$ decrease respectively) $(\mathrm{P}<0.025$ and $\mathrm{P}<0.001$ ), and restored almost to normal after 2 weeks of parabiosis. Renal $\alpha$-mannosidase activity was decreased $43 \%(\mathrm{P}<0.001)$ in the diabetic mice but unaffected by parabiosis. Serum $\beta$-N-acetylglucosaminidase, $\beta$-galactosidase and $\alpha$-glucosidase activities were significantly increased in diabetic mice $(179 \% ; 233 \%$ and $58 \%$ increase respectively) $(P<0.005, P<0.001$ and $P<0.001)$, and returned to normal with parabiosis.

Key words: Spontaneously diabetic mice, non-obese diabetic mice, kidney glycosidase activities, $\alpha-\& \beta$ glycosidase, parabiosis, diabetic control, diabetes.

Capillary basement membrane thickening and deposition of basement membrane-like material in renal glomeruli are characteristic of the diabetic state. This could be due to either increased basement membrane glycoprotein synthesis or decreased glycoprotein metabolism. Glycosidases, lysosomal enzymes, participate in the catabolism of glycoproteins [1]. In previous reports, we have described a decrease in the activities of $\alpha$ - and $\beta$-glycosidases in the kidneys of streptozotocin diabetic rats [2-4] and also a moderate decrease in the hereditary mildly diabetic NSY mice [5]. In contrast, serum glycosidase activities were elevated in diabetic animals. If these changes were secondary to the diabetic state rather than to differences in species or strains, then enzyme activities should return to normal with effective treatment of the diabetic disorder. Normalization of kidney enzyme activities has been reported after insulin treatment in rats [2-4] but this was not confirmed in NSY mice [5].

Recently a non-obese diabetic strain of mouse was inbred in Shionogi laboratories (Japan) [6]. These mice were severely diabetic due to insulitis. We have used these mice to confirm the changes in $\alpha$ and $\beta$-glycosidases found in other mice and rats. By using parabiosis with normal control mice the effects of improved blood glucose regulation on the activities of renal enzymes have also been studied.

\section{Materials and Methods}

Diabetic mice were detected and inbred as follows in Shionogi laboratory. Details have been published elsewhere [6]. By chance, spontaneous diabetes was noted in inbred CTS (the registered Japanese name of this inbred strain) mice derived from the ICR strain (also a registered name of this inbred strain in Japan). Thereafter, litter mates were inbred for more than 10 generations. The spontaneously diabetic mice were no different from nondiabetic ICR strain mice until the onset of diabetes. Eighty percent of female mice became diabetic at around 90 days old and died 4 weeks later with blood glucose levels of approximately $600 \mathrm{mg} /$ $100 \mathrm{ml}$, and severe weight loss. Male mice became diabetic less frequently and the diabetes was less severe. Islets from diabetic mice showed insulitis with lymphocytic infiltration [6].

In the present studies diabetic female mice were fed ad libitum with water and oriental standard laboratory chow until 2 weeks after the onset of sudden severe diabetes and then sacrificed with age-matched ICR strain control mice, for blood glucose and 
Table 1. Blood glucose and serum insulin levels of control and diabetic mice before and 2 weeks after parabiosis

\begin{tabular}{|c|c|c|c|}
\hline & \multirow[t]{2}{*}{ Control } & \multicolumn{2}{|l|}{ Diabetic } \\
\hline & & before & after \\
\hline Number of animals & (5) & & (5) \\
\hline $\begin{array}{l}\text { Blood glucose } \\
(\mathrm{mg} / 100 \mathrm{ml})\end{array}$ & $165 \pm 12$ & $452 \pm 73$ & $260 \pm 51$ \\
\hline Insulin $(\mu \mathrm{U} / \mathrm{ml})$ & $79.0 \pm 14.0$ & $1.0>$ & $\begin{array}{l}46.0 \pm 18.0 \\
\mathrm{x}\end{array}$ \\
\hline
\end{tabular}

$\mathrm{xx} P<0.001 \quad \mathrm{x} P<0.05$

enzyme activity measurements. Parabiosis was established in some of the diabetic mice after blood sugar determination at 2 weeks of illness. They were then kept 2 more weeks and sacrificed, when blood glucose and enzyme activities were measured with agematched normoglycaemic controls. Blood was drawn from the common iliac vein under ether anaesthesia. All animals were sacrificed without fasting around noon. Blood glucose, serum insulin concentration, and enzyme activities were determined.

The kidney and liver were taken out and washed in cold $0.9 \mathrm{~g} /$ $100 \mathrm{ml}$ saline as previously described [2]. These procedures were done at $4{ }^{\circ} \mathrm{C}$ unless otherwise stated. Tissue was homogenized in 9 volumes of $0.01 \mathrm{~mol} / 1$ sodium phosphate buffer, $\mathrm{pH} 6.0$, and centrifuged at $1,000 \mathrm{~g}$ for $10 \mathrm{~min}$.

Enzyme activities were assayed using substrates and buffers as stated below by modified methods of Leaback and Walker [7] and Robinson [8], except for $\alpha$-mannosidase which was measured by a method modified from Chonchie et al. [9]. $\beta-\mathrm{N}$-Acetylglucosaminidase (EC 3.2.1.29) was measured using $0.2 \mathrm{~m} \mathrm{~mol} / 14$ methylumbelliferylglucosaminide (4-MU- $\beta$-N-acetylglucosaminide) in $0.02 \mathrm{mmol} / 1$ citrate buffer $\mathrm{pH} 4.4 ; \beta$-galactosidase (EC 3.2 .1 .23 ) using $0.5 \mathrm{mmol} / 1$ 4-MU- $\beta$-galactoside in $0.02 \mathrm{~mol} / 1$ citrate-phosphate buffer $\mathrm{pH} 3.7 ; \alpha$-glucosidase (EC 3.2.1.21) using $0.5 \mathrm{mmol} / \mathrm{l}$ 4-MU- $\alpha$-glucoside in $0.02 \mathrm{~mol} / \mathrm{l}$ citrate-phosphate buffer pH 6.0; $\alpha$-mannosidase (EC 3.2.1.24) using $6 \mathrm{mmol} / 1$ p-nitrophenol- $\alpha$-mannoside in $0.125 \mathrm{~mol} / 1$ acetate-sodium hydroxide buffer pH 5.0. Incubation time was $30 \mathrm{~min}$ at $37^{\circ} \mathrm{C}$. Reactions were stopped with $0.5 \mathrm{~mol} / 1$ glycine-sodium hydroxide buffer, $\mathrm{pH} 10.45$.

Blood glucose was measured by a glucose oxidase method. Serum insulin was measured by a double antibody method [10] using a Dainabot Insulin RIA kit. Sensitivity was 1 to $2 \mu \mathrm{U} / \mathrm{ml}$ and intra-assay coefficient variation $4-6 \%$. All results are expressed as mean \pm SEM and significance sought by Student's test, except blood glucose and serum insulin before and after parabiosis for which Wilcoxon's non-parametric test for paired comparisons was used.

\section{Results}

Blood glucose levels of the diabetic mice were $680 \pm$ $6 \mathrm{mg} / 100 \mathrm{ml}$ and serum insulin levels were $1.0>$ $\mu \mathrm{U} / \mathrm{ml}$ ( 7 animals). In a further series of diabetic mice ( 5 animals) blood glucose levels were lowered significantly from $452 \pm 73$ to $260 \pm 51 \mathrm{mg} / 100 \mathrm{ml}$ after 2 weeks of parabiosis and serum insulin levels were increased significantly to $46.0 \pm 18.0 \mu \mathrm{U} / \mathrm{ml}$ from $>1.0 \mu \mathrm{U} / \mathrm{ml}$. The values after parabiosis were not significantly different from those of control mice (Table 1).

Kidney $\beta$-N-acetylglucosaminidase and $\beta$-galactosidase activities were markedly decreased in diabetic mice and restored to almost normal by parabiosis (Table 2). $\alpha$-Mannosidase activities were also low in diabetic mice but unaffected by parabiosis.

Serum activities of $\beta$-N-acetylglucosaminidase, $\beta$-galactosidase and $\alpha$-glucosidase were markedly higher in the spontaneously diabetic mice, and returned to normal with parabiosis, but $\alpha$-mannosidase activity was not changed significantly (Table 3 ). Liver glycosidase activities are shown in Table 4. No significant changes were observed.

\section{Discussion}

Since lysosomal enzymes catalyse the metabolism of glycoproteins [1], the altered activities of these enzymes could be important in the pathogenesis of diabetic microangiopathy. Marked decreases in the activities of $\alpha$ - and $\beta$-glycosidases have been observed in the streptozotocin diabetic rat kidney [2-4], and a significant decrease in $\beta$-galactosidase and $\alpha$-mannosidase activities has been shown in kidneys of spontaneously mildly diabetic NSY mice [5]. In the present study, activities of $\alpha$ - and $\beta$-glycosidases were greatly decreased in the kidneys of the severely hyperglycemic spontaneously diabetic mice, but were normal in the liver. Glycosidase activities differ in various species and even in various strains. Therefore a significant decrease in glycosidase activities in the kidneys of hereditary diabetic mice might be due to variability among the different lines. To rule out this possibility and to show that these decreases in renal enzyme activities were induced by the diabetes itself, improvement of the diabetic state by parabiosis was attempted. As a result blood glucose levels were decreased and serum insulin levels increased to values comparable to those of control non-diabetic animals. This resulted in normalization of kidney activities of $\beta$-N-acetylglucosaminidase, $\beta$-galactosidase and $\alpha$-glucosidase, emphasising the importance of diabetic state in causing the original abnormality. It is uncertain from the present data if the fall in blood glucose or the rise in serum insulin was more important in reversing the enzyme changes.

We conclude from this work that activities of some of the $\alpha$ - and $\beta$-glycosidases in the kidney were markedly decreased in spontaneously diabetic mice and restored to normal by metabolic control of the diabetic state. These data are similar to previous observations of kidney enzymes in streptozotocin 
Table 2. Kidney glycosidase activities of control, diabetic, and parabiotic-diabetic mice

\begin{tabular}{|c|c|c|c|c|}
\hline \multirow[b]{2}{*}{ Number of animals } & \multicolumn{4}{|c|}{ Enzyme activities } \\
\hline & $\begin{array}{l}\text { Control } \\
\text { (5) }\end{array}$ & $\begin{array}{l}\text { Diabetic } \\
\text { (7) }\end{array}$ & $\begin{array}{l}\text { Parabiotic- } \\
\text { diabetic } \\
\text { (5) }\end{array}$ & \\
\hline$\beta$-N-acetylglucosaminidase & 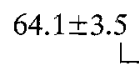 & $\underbrace{37.3 \pm 3.6}$ & $52.0 \pm 4.0$ & \\
\hline$\beta$-galactosidase & $20.6 \pm 1.4$ & $10.2 \pm 1.3$ & $17.8 \pm 2.9$ & $\begin{array}{l}\text { 4-methylumbelliferone } \\
\text { formation } \mu \mathrm{mol} / \mathrm{h} / \mathrm{g} \text { tissue }\end{array}$ \\
\hline$\alpha$-glucosidase & $14.8 \pm 1.0$ & $15.8 \pm 0.9$ & $18.0 \pm 1.3$ & \\
\hline$\alpha$-mannosidase & $42.0 \pm 0.6$ & $24.1 \pm 2.4$ & $25.7 \pm 2.3$ & p-nitrophenol formation $\mu \mathrm{mol} / \mathrm{h} / \mathrm{g}$ tissue \\
\hline
\end{tabular}

Table 3. Serum glycosidase activities of control, spontaneously diabetic and parabiotic-diabetic mice

\begin{tabular}{|c|c|c|c|}
\hline \multirow[b]{2}{*}{ Number of animals } & \multicolumn{3}{|c|}{ Enzyme activities (4-methylumbelliferone formation $\mu \mathrm{mol} / \mathrm{h} / \mathrm{ml}$ serum) } \\
\hline & $\begin{array}{l}\text { Control } \\
(5)\end{array}$ & $\begin{array}{l}\text { Diabetic } \\
(7)\end{array}$ & $\begin{array}{l}\text { Parabiotic-diabetic } \\
\text { (5) }\end{array}$ \\
\hline$\beta$-N-acetylglucosaminidase & $1.305 \pm 0.115$ & $3.650 \pm 0.610$ & $1.218 \pm 0.068$ \\
\hline$\beta$-galactosidase & $0.237 \pm 0.038$ & ]$_{j}^{0.790 \pm 0.130}$ & $0.354 \pm 0.115$ \\
\hline$\alpha$-glucosidase & $0.741 \pm 0.119$ & $1.171 \pm 0.131$ & $0.772 \pm 0.180$ \\
\hline
\end{tabular}

$\mathrm{xx} \mathrm{P}<0.001 \quad \mathrm{xP}<0.05$

Table 4. Liver enzyme activities of control, diabetic and parabiotic-diabetic mice

\begin{tabular}{|c|c|c|c|c|}
\hline \multirow[b]{2}{*}{ Number of animals } & \multicolumn{3}{|c|}{ Enzyme activities } & \\
\hline & $\begin{array}{l}\text { Control } \\
\text { (5) }\end{array}$ & $\begin{array}{l}\text { Diabetic } \\
\text { (7) }\end{array}$ & $\begin{array}{l}\text { Parabiotic- } \\
\text { diabetic } \\
\text { (5) }\end{array}$ & \\
\hline$\beta$-N-acetylglucosaminidase & $42.2 \pm 4.0$ & $45.4 \pm 6.1$ & $57.1 \pm 12.2$ & \\
\hline$\beta$-galactosidase & $11.4 \pm 2.1$ & $21.8 \pm 5.8$ & $21.8 \pm 5.8$ & 4-methylumbelliferone \\
\hline$\alpha$-glucosidase & $20.1 \pm 2.5$ & $24.2 \pm 2.8$ & $30.7 \pm 3.4$ & formation $\mu \mathrm{mol} / \mathrm{h} / \mathrm{g}$ tissue \\
\hline$\alpha$-mannosidase & $27.0 \pm 3.3$ & $23.6 \pm 1.9$ & $28.3 \pm 3.4$ & p-nitrophenol formation $\mu \mathrm{mol} / \mathrm{h} / \mathrm{g}$ tissue \\
\hline
\end{tabular}

None of changes is significant

diabetic rats. The decreases in glycosidase activities may be related to decreased breakdown of glycoprotein.

\section{References}

1. Mahadeban S, Dillard CJ, Tappel AL (1969) Degradation of polysaccharides, mucopolysaccharides, and glycoproteins by lysosomal glycosidases. Arch Biochem Biophys 129: 525-533
2. Fushimi H, TaruiS (1974) Kidney and serum $\beta$-N-acetylglucosaminidase activities in streptozotocin diabetic rats and their responses to insulin and glucagon. J Biochem (Tokyo) 76: $225-227$

3. Fushimi $H$, Tarui $S$ (1976) $\beta$-Glycosidases and diabetic microangiopathy. I. Decreases of $\beta$-glycosidase activities in diabetic rat kidney. J Biochem (Tokyo) 79: 265-270

4. Fushimi H, Tarui S (1977) Decrease in glycosidase activities in diabetic kidney. In: Bajaj JS (ed) Proceedings of the IX congress of the international diabetes federation, New Delhi, 1976. Excerpta Medica, Amsterdam, p 595-603 
5. Fushimi H, Shibata M, Tarui S (1980) Glycosidase activities in the liver and kidney of hereditary diabetic mice. J Biochem (Tokyo) 87: 941-949

6. Makino S, Kunimoto K, Muraoka Y, Mizushima Y, Katagiri K, Tochino $Y$ (1980) Breeding of a nonobese, diabetic strain of mouse. Exp Animals 29: 1-13

7. Leaback DH, Walker PC (1961) Studies of glucosaminidase 4. The fluorimetric assay of $\mathrm{N}$-acetyl- $\beta$-glucosaminidase. Biochem J 78: 151-156

8. Robinson D, Price RG, Dance N (1967) Separation and properties of $\beta$-galactosidase, $\beta$-glucosidase, $\beta$-glucuronidase and $\mathrm{N}$-acetyl- $\beta$-glucosaminidase from rat kidney. Biochem $\mathbf{J} 102$ : $525-532$

9. Chonchie J, Findlay J, Lerry GA (1959) Mammalian glycosidases; Distribution in the body. Biochem J 71: 318-325
10. Yalow RS, Berson SA (1960) Immunoassay of endogenous plasma insulin in man. J Clin Invest 39: 1157-1175

Received: August 10, 1979,

and in revised form: February 1, 1980

Hisako Fushimi

Department of Medicine

Sumitomo Hospital

2-2, 5-Chome, Nakanoshima, Kita-ku

Osaka, 530

Japan 